Article

\title{
Hurricanes as a Major Driver of Coastal Erosion in the Mississippi River Delta: A Multi-Decadal Analysis of Shoreline Retreat Rates at Bay Champagne, Louisiana (USA)
}

\author{
Marianne E. Dietz ${ }^{1, *}$, Kam-biu Liu ${ }^{1}\left(\mathbb{D}\right.$ and Thomas A. Bianchette ${ }^{2}$ \\ 1 Department of Oceanography and Coastal Sciences, College of the Coast and Environment, \\ Louisiana State University, Baton Rouge, LA 70803, USA; kliu1@lsu.edu \\ 2 Department of Natural Sciences, University of Michigan-Dearborn, Dearborn, MI 48128, USA; \\ tbianc@umich.edu \\ * Correspondence: mdietz2@1su.edu; Tel.: +1-225-578-0470
}

Received: 24 September 2018; Accepted: 16 October 2018; Published: 19 October 2018

\begin{abstract}
The Louisiana shoreline is rapidly retreating as a result of factors such as sea-level rise and land subsidence. The northern Gulf of Mexico coast is also a hotspot for hurricane landfalls, and several major storms have impacted this region in the past few decades. A section of the Louisiana (USA) coast that has one of the highest rates of shoreline retreat in North America is the Caminada-Moreau headland, located south of New Orleans. Bay Champagne is a coastal lake within the headland that provides a unique opportunity to investigate shoreline retreat and the coastal effects of hurricanes. In order to examine the influence of hurricanes on the rate of shoreline retreat, 35 years (1983-2018) of Landsat imagery was analyzed. During that period of time, the shoreline has retreated $292 \mathrm{~m}$. The overall rate of shoreline retreat, prior to a beach re-nourishment project completed in 2014, was over $12 \mathrm{~m}$ per year. A period of high hurricane frequency (1998-2013) corresponds to an increased average shoreline retreat rate of $>21 \mathrm{~m}$ per year. Coastal features created by multiple hurricanes that have impacted this site have persisted for several years. Bay Champagne has lost $48 \%$ of its surface area over the last 35 years as a result of long-term shoreline retreat. If shoreline retreat continues at the average rate, it is expected that Bay Champagne will disappear completely within the next 40 years.
\end{abstract}

Keywords: shoreline retreat; coastal erosion; hurricanes; Mississippi River Delta

\section{Introduction}

Many coastal zones throughout the world are increasingly vulnerable to shoreline retreat [1-4]. A multitude of environmental factors, such as accelerated sea level rise, coastal subsidence, and enhanced storm activity, are thought to contribute to the process of shoreline retreat in different coastal regions and geomorphological settings. The processes driving shoreline retreat are likely exacerbated by the influence of human activities, such as diminished sediment supply through dam and levee construction and altered shoreline configuration due to coastal development [5-7]. The complex interplay between the various environmental and anthropogenic factors act in different combinations in different coastal environments, and their relative importance also differs from one region to another.

The shoreline along the northern Gulf of Mexico is rapidly retreating and has undergone significant morphological changes due to complex erosional and subsidence processes. In Louisiana (USA), the rates of coastal retreat and land loss are among the highest in the world [1,8-11]. A combination of several factors are responsible for these high rates of shoreline retreat, including 
sea-level rise, the subsidence and compaction of Holocene deltaic sediments, and reduced sediment supply due to the construction of dams and levees [12,13]. Compaction of sediments over time causes coastal land subsidence. This phenomenon, coupled with eustatic sea-level rise, creates a relative sea-level rise in this region that is nearly three times higher than the global average [14].

One region of the Louisiana coast that has a particularly high rate of shoreline retreat is the Caminada-Moreau headland (Figure 1). Previous work has analyzed shoreline retreat rates at a state or regional scale [10,15-17], but shoreline retreat rates have been shown to vary within a single stretch of this coastline even under the same forcing conditions [16]. It is therefore important to analyze the impacts from a single site at high temporal resolution to accurately capture the extent of coastal change over many years. In this study, we use satellite imagery analysis to provide an annual-scale reconstruction of the pattern and rates of shoreline retreat over a 35-year period (1983-2018) for a small, rapidly retreating section of barrier beach in the Caminada-Moreau headland. The goals of this study are twofold: to quantify shoreline retreat at a specific site on the Caminada-Moreau headland over the past few decades, and to ascertain the influence of hurricanes on the rate of shoreline retreat. This case study from the Louisiana coast can be considered a microcosm of the processes driving shoreline retreat throughout the Gulf of Mexico.

\section{Study Region}

Located south of New Orleans, the Caminada-Moreau headland has one of the highest rates of shoreline retreat in North America [8,11,15,18-20]. This stretch of coastline was once part of the Lafourche Delta lobe that was abandoned by the Mississippi River within the last 1000 years $[15,19,21]$. Since then, the morphology of the Caminada-Moreau headland has changed considerably, particularly over the past century. Several studies using maps from the late 1800s have documented significant land loss in this region $[8,10,15,17,19]$. Since that time, the shoreline in this region has retreated several kilometers inland $[8,17]$. Though different portions of this coastline were shown to have different rates of retreat $[15,19]$, there are some indications that shoreline retreat along the Caminada-Moreau headland is accelerating in recent years [8,22].

A major factor of shoreline retreat on the Caminada-Moreau headland is that sediment erosion greatly exceeds deposition. This region is considered sediment-starved and is not hydrologically connected to either the Mississippi River or the Atchafalaya River. The headland receives some sediment via the Bayou Lafourche distributaries, but the primary sediment source is re-worked sediment from the Cheniere Caminada beach-ridge plain $[10,23]$. Shoreline erosion supplies sediment for barrier island development at either end of the headland. The system has a total net sediment loss of $5.6 \times 10^{5} \mathrm{~m}^{3} / \mathrm{yr}$, with less than $5 \%\left(0.3 \times 10^{5} \mathrm{~m}^{3} / \mathrm{yr}\right)$ of that lost sediment redeposited elsewhere within the system [15]. The primary mechanism for sediment loss on the Caminada-Moreau headland is thought to be longshore transport [15]. The predominant onshore wave approach is from the southwest and much of the longshore transport occurs in an eastward direction [15]. This results in erosion rates that are higher on the western end of the headland and decrease to the east [15]. Locally generated wind waves can also move sediment to the southwest [15], though longshore transport in this direction has been altered by the construction of jetties and breakwaters.

Another mechanism of shoreline retreat in this region is sea-level rise. The Caminada-Moreau headland has one of the highest rates of sea-level rise in North America. The average rate of relative sea-level rise at Grand Isle, LA (located at the eastern end of the headland) is about $1 \mathrm{~cm} / \mathrm{yr}[9,24]$. Subsidence rates, which contribute to relative sea-level rise rates, are also quite high in this region, with estimates ranging from $5-12 \mathrm{~mm} / \mathrm{yr}[25,26]$. Over the past century, the headland has subsided nearly $2.5 \mathrm{~m}$ [27]. Since this region lacks input of new sediment, the shoreline cannot keep pace with rising sea level and further erosion occurs.

Storms are a particularly important driver of shoreline morphology on the Caminada-Moreau headland. This stretch of coast is described as "storm-dominated" $[27,28]$ and is more sensitive to storm-induced coastal geomorphic change than other coastal areas in Louisiana due to its sediment 
starved nature. Winter storms are relatively low energy events, though the cumulative impact of winter storms can be a gradual but significant influence on shoreline morphology [29,30]. These frontal systems typically occur approximately 20-30 times per year, typically between October and April. Winter storms can change the mean water level in this region by up to a meter [31] and cause significant sediment transport [32-34]. There is little interannual variability in the timing and frequency of winter storms in this region, so the coastal effects of these storms are expected to remain relatively constant [35].

Hurricanes occur far less frequently than winter storms but have sufficient energy to cause dramatic shoreline changes in a short time. Coastal Louisiana is a hotspot for hurricane landfalls. Multiple hurricanes, including Katrina (2005), Rita (2005), Ike (2008), Gustav (2008), and Isaac (2012) have affected the Mississippi River delta region within the last few decades alone [8,36,37]. Several studies have shown that hurricanes are important sediment sources to coastal environments and play a crucial role in the erosion, transport, and deposition of coastal sediments in Louisiana [36-40]. Hurricanes can cause storm surge in excess of $6 \mathrm{~m}$ in the northern Gulf of Mexico [10,23], which is more than high enough to overtop any of the barrier beaches on the Caminada-Moreau headland [23] and can rapidly cause both ephemeral and permanent alterations to coastal features. Such storms therefore play an important role in the morphological evolution of coastlines.

Coastal erosion and shoreline retreat create not only environmental concerns for the Caminada-Moreau headland, but also economic concerns. Port Fourchon, located near the southwest end of the headland, is home to one of the largest oil and gas infrastructures on the Gulf coast. The port supports more than $90 \%$ of the deepwater drilling efforts in the Gulf of Mexico, and is a significant economic influence in this region [41]. A series of jetties and offshore breakwaters, constructed for navigation purposes and to protect Port Fourchon, are located just to the southwest of Bay Champagne and influence longshore sediment transport. The construction of these structures, as well as the dredging of local navigation channels, began as early as the 1930s [42].

A recent effort to combat shoreline retreat completed in 2014. A beach re-nourishment project, initiated in 2013, added sand dredged from offshore to the Caminada-Moreau headland beach. Approximately $2.8 \times 10^{6} \mathrm{~m}^{3}$ of dredged sediment was used to re-nourish the beaches in front of Port Fourchon and Bay Champagne which widened the beach and elevated the dunes in an effort to protect local wetlands and slow shoreline retreat [43]. This project re-nourished about $9.5 \mathrm{~km}$ of beach and resulted in the creation of over $1.5 \mathrm{~km}^{2}$ of beach and dunes [43].

\section{Study Site}

Bay Champagne $\left(29^{\circ} 6^{\prime} 56^{\prime \prime} \mathrm{N}, 90^{\circ} 10^{\prime} 40^{\prime \prime} \mathrm{W}\right)$ is a semi-circular coastal lake situated on the southwestern end of the Caminada-Moreau headland near Port Fourchon (Figure 1). The lake is brackish and very shallow, with a median depth of about $2 \mathrm{~m}$. Bay Champagne and the rest of the Caminada-Moreau headland is not influenced by the Mississippi or Atachafalaya Rivers. The site is microtidal, with an average tidal range of less than $0.4 \mathrm{~m}$. The only freshwater sources are local precipitation and Bayou Lafourche. The lake is surrounded by mangrove and saltmarsh vegetation. Navigation channels provide access between Bay Champagne and the Port Fourchon area, but there is no current direct connection to the Gulf of Mexico. Intermittent connections to the Gulf have occurred in the past through breaching of the relatively narrow barrier beach and dune which separates the lake from the Gulf [44]. Though these breaches are generally ephemeral, they can temporarily alter the water circulation pattern of the lake and surrounding mangrove marshes.

The barrier beach of the Caminada-Moreau headland is shaped by variable longshore currents, particularly near Bay Champagne. Though predominant longshore transport direction is to the northeast, closer to Bay Champagne sediment transport occurs both to the northeast and the southwest [27,44]. This is largely due to navigation control structures and breakwaters near Port Fourchon [15]. The beach at Bay Champagne serves as a sediment source for much of the rest of the headland; it is estimated 
that up to $40 \%$ of the annual sediment loss on the Caminada-Moreau headland is from this stretch of beach [15].

Bay Champagne is an ideal site to study the effects of hurricanes on coastal erosion and shoreline retreat in Louisiana due to the high frequency of hurricane strikes in this region and the vulnerability of the site to storm surge inundation. The relatively low dune that separating the lake from the Gulf has one of the lowest elevations on the Caminada-Moreau headland [23] and can easily be overtopped by a storm surge in excess of $1.2 \mathrm{~m}$ [19]. Evidence of overwash is preserved in Bay Champagne as a large depositional fan and sand layers in the lake itself $[45,46]$.

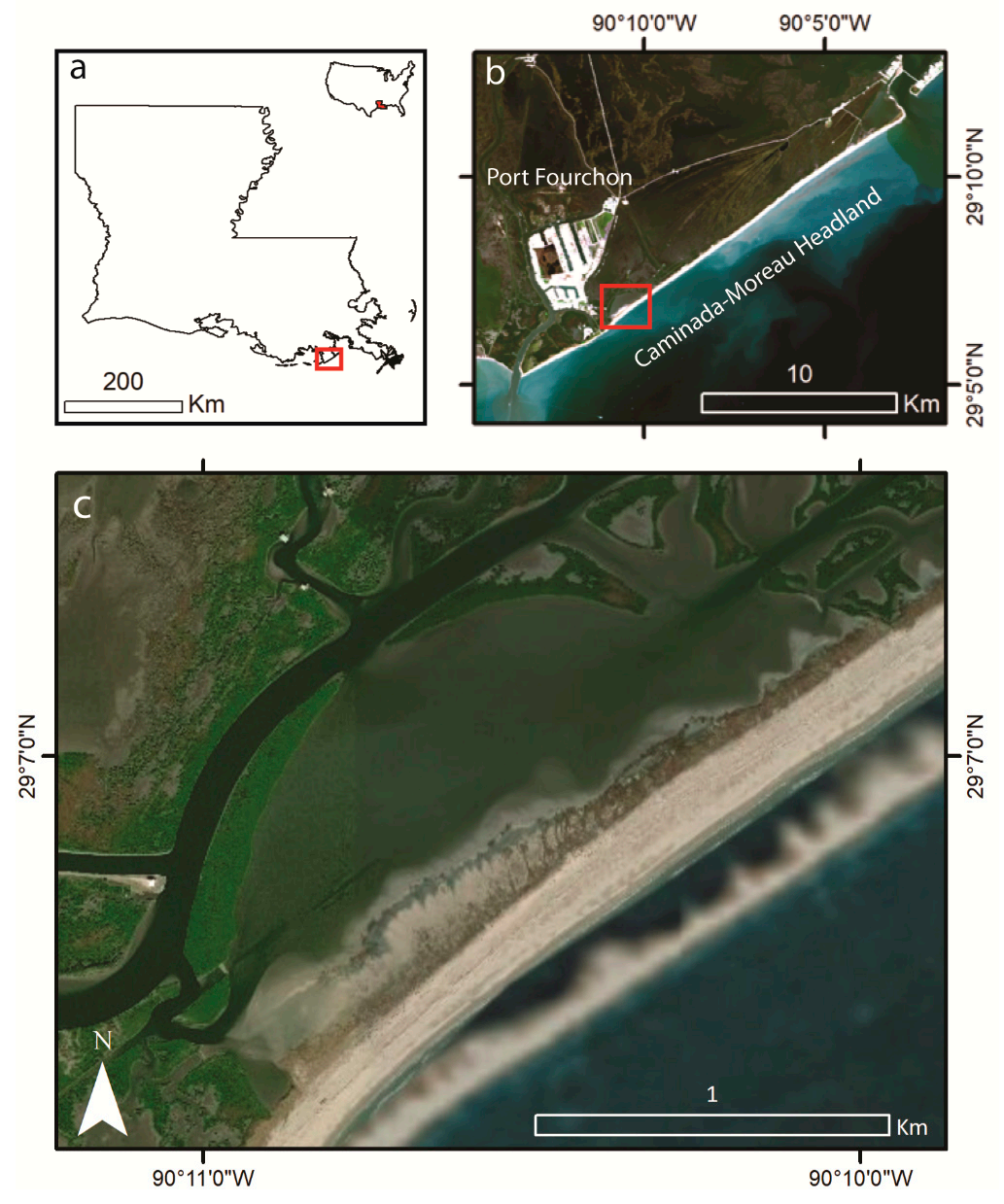

Figure 1. Bay Champagne is located on the coast of south-eastern Louisiana (a), on the southwestern part of the Caminada-Moreau Headland (b). Port Fourchon, an important base for oil and gas operations in the Gulf of Mexico, is situated less than $2 \mathrm{~km}$ to the northwest of this site. Bay Champagne is a shallow, semi-circular coastal lake separated from the Gulf of Mexico by a barrier beach (c). Image credits: Landsat 8 (b), and ESRI (c).

\section{Materials and Methods}

\subsection{Imagery}

Landsat 5 (1983-2011) and Landsat 8 (2013-2018) imagery was used to track shoreline change at Bay Champagne for the past 35 years. A total of 34 cloud-free, geometrically corrected Level 1 data product images were used, obtained from the USGS. Images were not available for 2012. Images were acquired for October of each year, if available, to facilitate annual shoreline position comparisons. Since October is near the end of the North Atlantic hurricane season, these images provide a reasonable compilation of yearly storm impacts. This month also contained the highest availability of cloud-free 
images over the study period. For years where cloud-free images were not available from October, cloud-free images were acquired from preceding and following months. An image from March was used for the year 2018. Images used to examine the shoreline changes due to hurricanes in 2005 and 2008 were selected based on acquisition dates before and after the storms.

\subsection{Methods}

Imagery analysis for this study was accomplished using ESRI ArcMap v10.5 software. Shoreline delineation was completed using an open-source toolbox "Landsat Toolbox for Shoreline Extraction" [47] to establish shoreline boundaries for each image. This toolbox utilized the tasseled cap transformation (to produce wetness, greenness, and brightness images) and the normalized difference vegetation index (NDVI; uses the NIR and red bands) to extract the shoreline in Landsat images [47]. These transformed bands were then used to perform an unsupervised classification to determine landcover classes, specifically land vs. water areas. These classes were used as a proxy for the shoreline to enable the identification of a definitive boundary. Shorelines were drawn along the clearly-defined boundaries between land and water. The results were then cropped to the area of interest around Bay Champagne. Results of the automatic shoreline delineation were visually inspected and edited as needed through comparison with the original satellite images. The resulting shapefiles were also edited to remove other areas of coastlines and wetlands that were unintentionally delineated. Lake and shoreline boundaries were reviewed and manually corrected as necessary to remove errors.

Shoreline change distances were measured (in meters) along three transects using ArcMap software. Transects were drawn in the center of the lake and equidistant on either side to compare shoreline movement across three points. These transects were spaced $550 \mathrm{~m}$ apart to cover the entirety of the lake without crossing into the surrounding marsh. To compare the overall area of Bay Champagne that was lost due to shoreline retreat, polygons were created from the shoreline shapefiles. Polygon areas were calculated using ArcMap. The total percentage of area lost was determined by calculating the difference between the earliest (1983) and latest (2018) polygons.

\section{Results}

The average shoreline retreat at Bay Champagne was approximately $292 \mathrm{~m}$ over the 35-year study period (Figure 2). The total amount of retreat varied over the three transects, with Transect A experiencing the least retreat $(246 \mathrm{~m})$ and Transect $C$ experiencing the greatest retreat $(336 \mathrm{~m})$. The overall rate of average annual shoreline retreat was $8.63 \mathrm{~m} / \mathrm{yr}$, with the average rates ranging from $7.29 \mathrm{~m} / \mathrm{yr}$ (Transect A) to $9.86 \mathrm{~m} / \mathrm{yr}$ (Transect C) (Table 1). The overall rate of retreat increased from the southwestern end to the northeastern end of the lake. Bay Champagne lost approximately $48 \%$ of its surface area since 1983 (Figure 2). The interior lake boundaries remained relatively stable over this time period.

Table 1. Average shoreline retreat rates for the three transects over four decades. Average rates per decade and per transect are also given. Negative values indicate shoreline progradation. Overall rates include the entire 35-year study period, while the 1983-2013 rates exclude the beach re-nourishment project.

\begin{tabular}{ccccc}
\hline \multicolumn{5}{c}{ Shoreline Retreat Rates $(\mathbf{m} / \mathbf{y r})$ by Decade } \\
\hline \multicolumn{5}{c}{ Transects } \\
\hline 1980s & 8.41 & 7.15 & $\mathrm{C}$ & Average \\
$1990 \mathrm{~s}$ & 8.12 & 8.67 & 9.09 & 8.01 \\
$2000 \mathrm{~s}$ & 17.69 & 17.11 & 18.51 & 17.77 \\
$2010 \mathrm{~s}$ & -8.39 & -1.53 & 0.01 & -3.30 \\
OVERALL: & 7.29 & 8.74 & 9.86 & 8.63 \\
1983-2013 & 11.49 & 12.35 & 13.90 & 12.58 \\
\hline
\end{tabular}




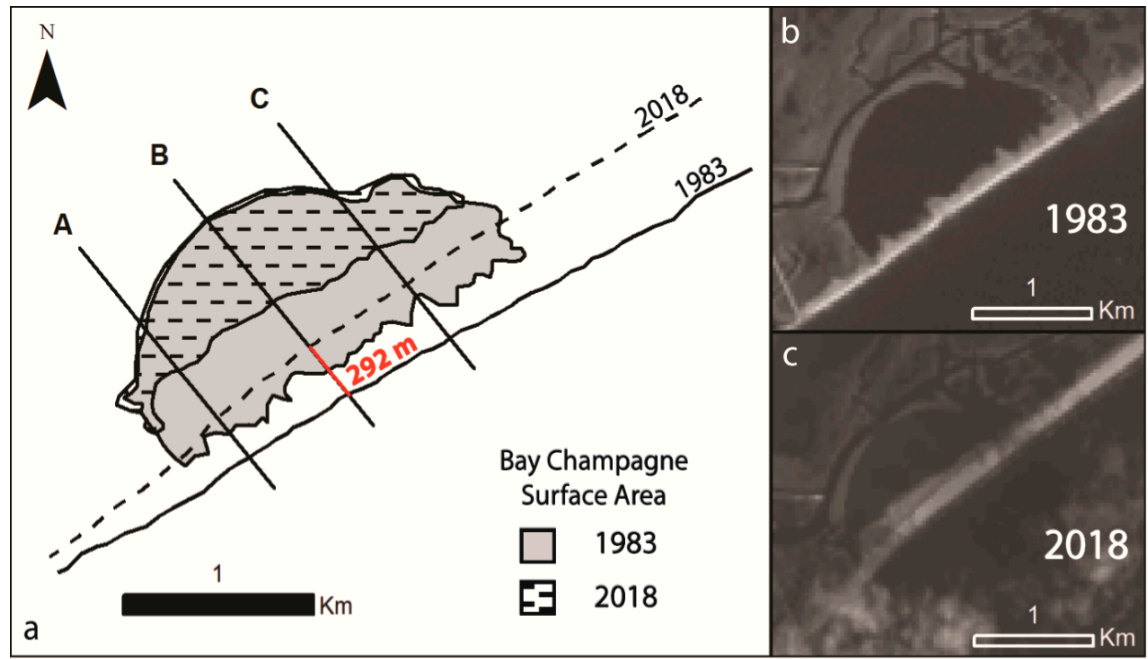

Figure 2. The shoreline position and surface area of Bay Champagne in 1983 (solid gray) and 2018 (dashed lines). The shoreline has retreated approximately $292 \mathrm{~m}$ during this 35-year period (a). The rapid retreat of the shoreline resulted in the loss of approximately $48 \%$ of the surface area of Bay Champagne. Lake area was derived in part from brightness images produced from Landsat imagery in 1983 (b) and 2018 (c).

\subsection{Decadal Retreat Rates}

Shoreline retreat at Bay Champagne was not constant over the 35-year period. Actual retreat distance varied from year to year and slight progradations were observed during some years (Figure 3). Rates of average retreat were determined by decade to investigate temporal changes (Table 1). The earliest period, 1983 to 1989, experienced an average rate of shoreline retreat of approximately $8 \mathrm{~m} / \mathrm{yr}$. The retreat rate was lower $(7.2 \mathrm{~m} / \mathrm{yr})$ in the center of the lake (Transect B) than at either end ( $8.4 \mathrm{~m} / \mathrm{yr}$ and $8.5 \mathrm{~m} / \mathrm{yr}$, Transects A and C, respectively). From 1990 to 1999, the average rate of retreat increased slightly to about $8.6 \mathrm{~m} / \mathrm{yr}$. The amount of shoreline retreat during this time frame was greater at the northeast end of the lake $(9.3 \mathrm{~m} / \mathrm{yr}$, Transect C) than at the southwest end $(8.1 \mathrm{~m} / \mathrm{yr}$, Transect A). From 1983-1999, shoreline retreat appears to have been largely linear.

The amount of shoreline retreat at Bay Champagne was greatest between 2000 and 2009. During this period, the average rate of shoreline retreat at all three transects climbed to over $17 \mathrm{~m} / \mathrm{yr}$, more than double the retreat rate of the preceding decades. The average retreat rate was slightly lower in the center of the lake (Transect B) than at either end, and the greatest retreat rate $(18.51 \mathrm{~m} / \mathrm{yr})$ occurred at the northeast end of the lake (Transect C).

During the most recent decade (2010-2018) shoreline retreat was reversed at Bay Champagne due to the beach nourishment project, which resulted in shoreline progradation of approximately $80 \mathrm{~m}$ (Figure 3). Shoreline position was relatively stable for four years after this project was complete. The rate of retreat prior to the beach nourishment project was much higher than the overall rate of retreat for the entire time period. However, the trend of greater retreat towards the northeast end of the lake was the same before and after the beach re-nourishment project.

A noticeable change between the 1990s and 2000s was the formation of major overwash fans behind the barrier beach, which led to a significant reduction in the size of the lake. Changes in the overwash fan behind the barrier beach were evident over the past 35 years (Figure 3). These changes, including small overwash features and minor breaches, are relatively small during the 1980s and 1990s. From 2000 to 2009, significant alterations of the overwash fan were evident, corresponding to several breaches of the beach which caused ephemeral connections to the Gulf of Mexico. The barrier beach became relatively stable after 2010 . 


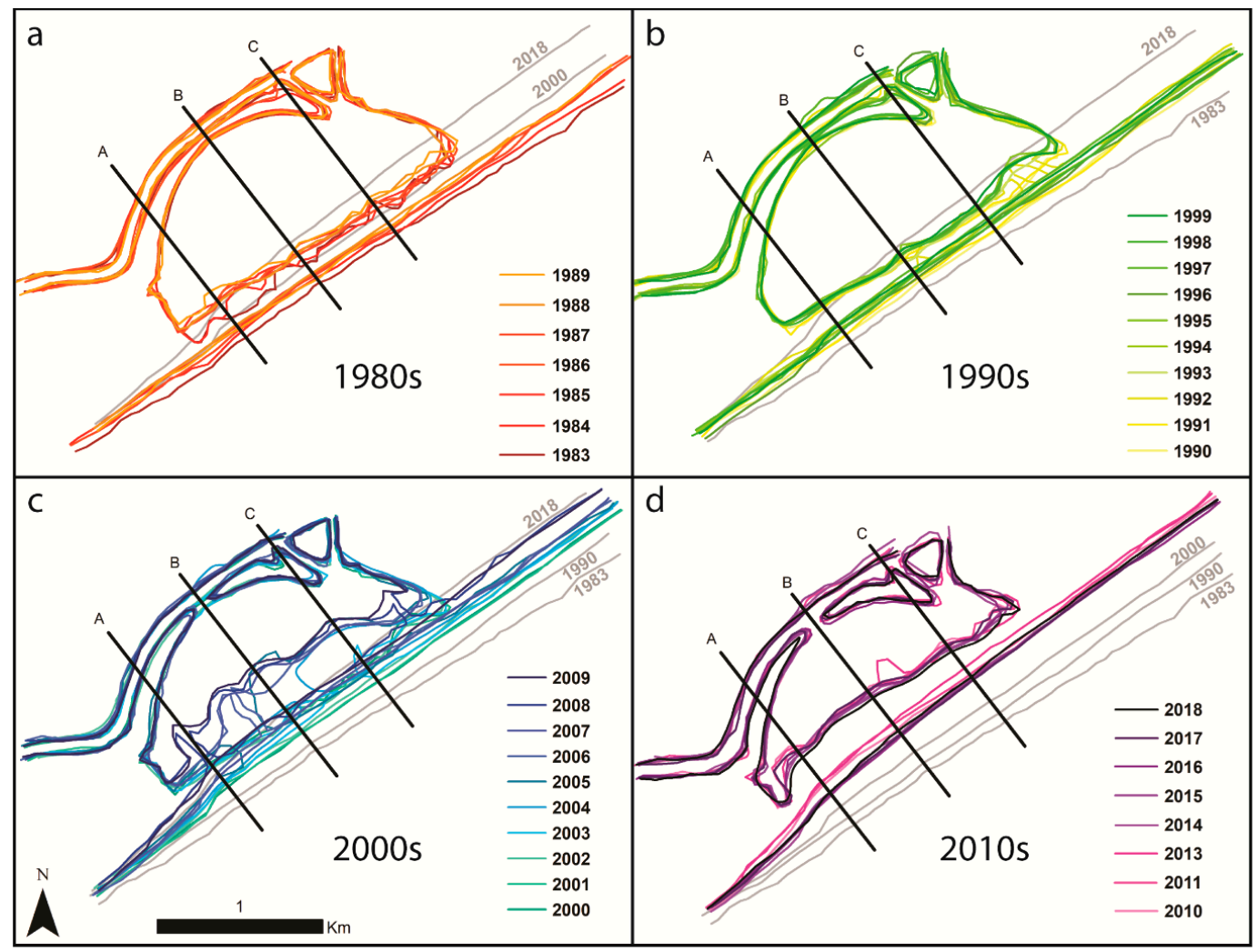

Figure 3. Annual positions of the shoreline and lake boundaries at Bay Champagne for the past 35 years. The shoreline positions are grouped by decade: (a) 1980s, (b) 1990s, (c) 2000s, and (d) 2010s. Gray lines representing shoreline positions in other decades are shown for comparison. Transects A, B, and C are black shore-normal lines in each panel and are used for reference to document shoreline changes.

\subsection{Case Studies-Hurricanes in 2005 and 2008}

Hurricane impacts were examined using two case studies. Two pairs of strong hurricanes impacted Bay Champagne in 2005 (Katrina, Rita) and 2008 (Gustav, Ike). These two years offer an ideal opportunity for comparison since the pair of hurricanes that occurred in each year include one hurricane that made landfall very close to Bay Champagne (Katrina in 2005, Gustav in 2008) and one hurricane that made landfall further to the west (Rita in 2005, Ike in 2008). These two years also had the highest total storm activity in the Gulf of Mexico over the 35-year study period. Cloud-free Landsat images were available immediately preceding and shortly after the passage of the storms, enabling comparisons of pre- and post-storm shoreline morphology and position.

Hurricane Katrina made landfall less than $75 \mathrm{~km}$ away from Bay Champagne as a Category 3 storm. Less than one month later, Hurricane Rita made landfall more than $350 \mathrm{~km}$ west of Bay Champagne and caused storm surge along the entire Louisiana coast [48]. The combined effects of both storms caused significant changes to the barrier beach at Bay Champagne. Pre-storm imagery from August 2005 showed a relatively continuous shoreline with two shallow breaches in the center of the barrier beach (Figure 4a, gray lines). Further imagery analysis indicated that these breaches in the beach had existed since at least March 2005. After the storms, these small breaches were replaced by a much larger breach in the southwest part of the barrier beach (Figure 4a, black lines). Additionally, there was extensive overwash in the northeastern side of the beach and a broadening of the overwash fan in this section. The other areas of Bay Champagne appear to have been unaffected by the storms. Minimal shoreline retreat occurred as a direct result of Hurricane Katrina and Rita, though some small-scale localized changes are evident. 


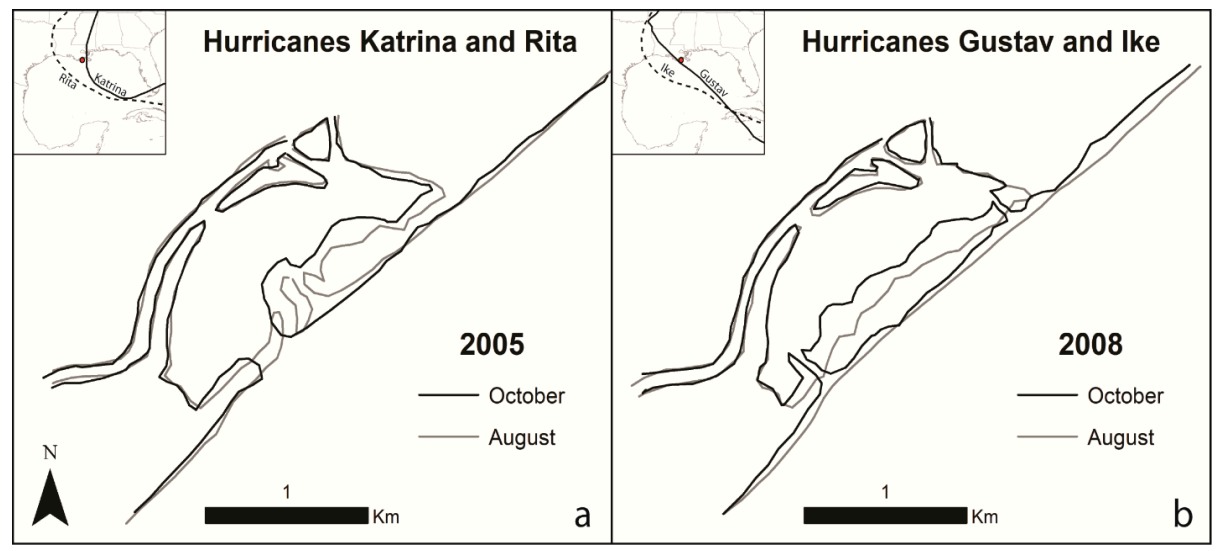

Figure 4. Shoreline morphology of Bay Champagne in response to two pairs of hurricanes: (a) Katrina and Rita in 2005 and (b) Gustav and Ike in 2008. Gray lines represent the shoreline prior to the storms in each year, and the black lines show the shoreline after the storms. Though the hurricanes in both years caused breaches in the barrier beach, the coastal effects of each pair of storms varied significantly.

In September of 2008, another pair of hurricanes impacted the northern Gulf Coast in rapid succession. Hurricane Gustav made landfall less than $50 \mathrm{~km}$ west of Bay Champagne as a Category 2 storm. Hurricane Ike impacted the Louisiana coast just over a week later before ultimately making landfall in Texas as a category 4 . The cumulative effect of these two storms led to widespread coastal flooding on the Louisiana coast [48]. The coastline morphology at Bay Champagne a few weeks prior to the passage of these storms is relatively linear, with no evidence of the 2005 breach (Figure $4 \mathrm{~b}$, gray lines). Less than one month after these two storms made landfall, the barrier beach shows clear signs of overwash as well as two small breaches at the north-eastern and south-western corners of the lake (Figure $4 \mathrm{~b}$, black lines). Extensive overwash is visible along the entire beach. Additionally, notable shoreline retreat occurred following Hurricanes Gustav and Ike. The shoreline retreated an average of about $50 \mathrm{~m}$, though the amount of retreat was not constant across the entire shoreline. As in 2005, no noticeable change is evident in the other areas of Bay Champagne.

\section{Discussion}

The shoreline at Bay Champagne is retreating at an extremely rapid rate. Over 35 years, the shoreline has migrated by an average of nearly $300 \mathrm{~m}$, or about $8.6 \mathrm{~m} / \mathrm{yr}$. This overall rate of retreat is somewhat lower than previous studies that reported a retreat rate of between $12-20 \mathrm{~m} / \mathrm{yr}$ for the Caminada-Moreau headland $[10,15,16,49]$. However, the overall retreat rate of $8.6 \mathrm{~m} / \mathrm{yr}$ includes the beach re-nourishment project, which artificially added over $80 \mathrm{~m}$ of shoreline and altered the natural process of shoreline retreat. The retreat rates are therefore skewed, and are thus not representative of the natural process of shoreline retreat. The retreat rate for the study period prior to completion of the beach re-nourishment project (1983-2013) was approximately $12.6 \mathrm{~m} / \mathrm{yr}$, which is comparable to the retreat rates previously reported.

\subsection{Spatial and Temporal Variations in Shoreline Retreat}

The amount of shoreline retreat differs slightly when comparing Transects A, B, and C. Transect $C$, located near the northeast side of the lake, tends to have higher rates of retreat than the other two transects. Transect A, on the southwest side of the lake, has the lowest overall rate of retreat. This difference is likely a result of the presence of offshore breakwaters constructed in the 1960s off of Belle Pass to the southwest of Bay Champagne. These breakwaters decreased the rate of shoreline erosion in other areas of the headland but accelerated coastal erosion directly in front of Bay Champagne $[8,17]$.

The shoreline retreat rate was not constant over the 35-year study period. The most recent rate decrease occurred after 2010 and can be largely attributed to the beach re-nourishment. The retreat 
rates in the 1980s and 1990s were relatively constant at approximately $8 \mathrm{~m} / \mathrm{yr}$, which more than doubled to over $17 \mathrm{~m} / \mathrm{yr}$ from 2000 to 2009. This dramatic increase in shoreline retreat rate between decades was consistent across all three transects with only minor variations. The 2000-2009 time period corresponds to a period of high storm activity in the Gulf of Mexico (Figure 5). Between 1998 and 2013, there were twice as many Gulf hurricanes as there were in the previous two decades. In addition, $75 \%$ of the storms that tracked within a $200 \mathrm{~km}$ radius of Bay Champagne occurred during this time frame. Presumably, storms that are more proximal to the site will have a greater impact on the shoreline.

\subsection{Hurricane Impacts on Shoreline Retreat}

Impacts from the increase in Gulf hurricanes appear to be reflected in the cumulative retreat of the shoreline at Bay Champagne (Figure 5, red line). The cumulative retreat represents the percentage of shoreline change based on the retreat from the starting position in 1983 (value $=0 \%$ ). The total cumulative retreat $(100 \%)$ represents the shoreline position in 2018 . The cumulative retreat of the shoreline is relatively gradual from 1983 until 1998, when retreat dramatically increases. This increase continues through 2013 when the cumulative retreat is approximately $120 \%$, indicating that the 2013 shoreline position was more landward than the 2018 shoreline position. Shoreline retreat was temporarily reversed in 2014 by the beach re-nourishment project, which moved the shoreline more than $80 \mathrm{~m}$ seaward of its previous position. The shoreline remained in the same location for three years after the beach re-nourishment project was completed, but in 2018 the shoreline appears to be retreating again.

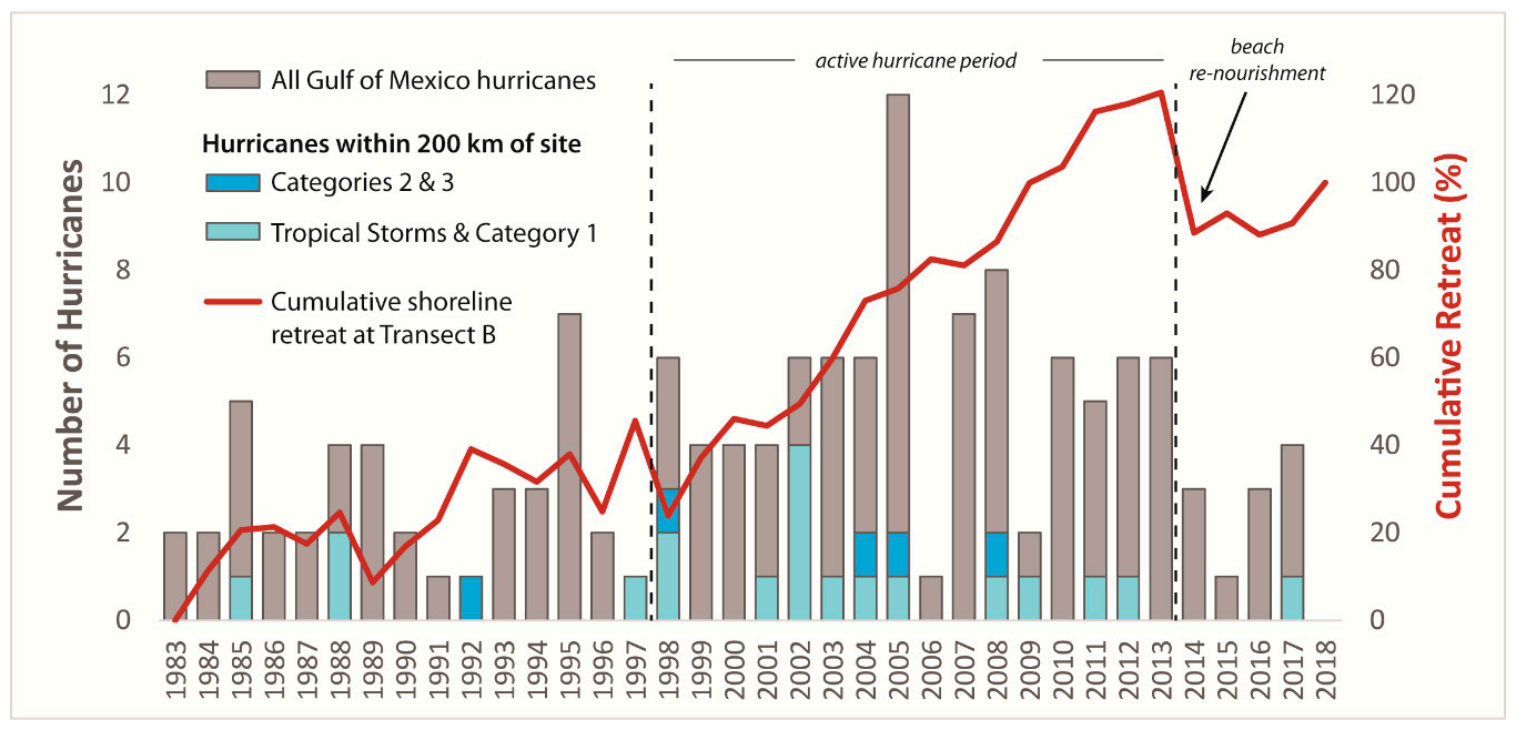

Figure 5. The number of hurricanes that occurred per year in the Gulf of Mexico from 1983 to 2017 are represented by gray bars. Storms that came within a $200 \mathrm{~km}$ radius of Bay Champagne are shown in shades of blue based on intensity at landfall (track data available in Figure S1). The cumulative shoreline retreat at Transect B in the center of Bay Champagne is shown as a red line and represents the change in shoreline position from 1983 (0\% cumulative retreat) to 2018 (100\% cumulative retreat). Shoreline progradation resulting from a beach re-nourishment project is evident as a sharp decrease in cumulative retreat in 2014 .

The increase in shoreline retreat is likely linked to the increase in Gulf hurricane frequency. The period of high hurricane frequency appears to have driven shoreline retreat at an accelerated rate. Therefore, it makes more sense to compare periods of high hurricane frequency, or stormy periods, with stretches of time when fewer hurricanes occurred, or quiet periods, to investigate the influence of hurricanes on shoreline retreat rates at Bay Champagne. The 35-year study period can then be divided into three periods: two quiet periods (1983-1997 and 2015-2018) and one stormy period (1998-2013) 
(Table 2). Data for the year 2014 was removed from the data set since that was the year that the beach re-nourishment project was completed.

Table 2. Shoreline retreat rates at Bay Champagne recalculated by periods of Gulf hurricane frequency rather than decade. Quiet periods have nearly identical average retreat rates, while the stormy period retreat rates are nearly five times higher than the quiet retreat rates. Note: 2014 values have been excluded from rate calculation due to beach restoration project.

\begin{tabular}{ccccc}
\hline \multicolumn{5}{c}{ Retreat Rate (m/yr) by Period } \\
\hline & $\mathbf{A}$ & $\mathbf{B}$ & $\mathbf{C}$ & Average \\
\hline Quiet (1983-1997) & 4.22 & 4.72 & 5.00 & 4.65 \\
Stormy (1998-2013) & 19.88 & 20.53 & 23.43 & 21.28 \\
Quiet (2015-2018) & 4.74 & 8.50 & 1.05 & 4.76 \\
OVERALL: & 9.61 & 11.25 & 9.83 & 10.23 \\
\hline
\end{tabular}

The average retreat value for the two quiet periods was nearly identical at about $4.7 \mathrm{~m} / \mathrm{yr}$ (Table 2). This rate is also consistent with the average retreat rate for the entire Louisiana coast $(4.3 \mathrm{~m} / \mathrm{yr})[16,49]$. This suggests that during the quiet periods with few hurricanes, other processes that cause shoreline retreat, such as sea-level rise, subsidence, and winter storms are the predominant drivers of shoreline retreat during these times. These processes occur at what can be considered constant rates over multi-decadal time scales and are not likely to have changed during the study period. The similarities in the retreat rates during the quiet periods of this study suggest this combination of factors represent "background" rates of shoreline retreat that operate independently of hurricane impacts.

Our study shows that hurricanes are a major factor causing accelerated shoreline retreat in Louisiana. Coastal erosion attributed to storm activity can happen in bursts, with episodes of greater than $50 \mathrm{~m}$ of shoreline loss recorded in a single year [44,49]. The average retreat rate at Bay Champagne during the stormy period was more than $21 \mathrm{~m} / \mathrm{yr}$, nearly five times higher than the retreat rate during the quiet periods. This rate is similar to the average rate of shoreline retreat calculated for the Chandeleur Islands, a chain of barrier islands located east of the active Mississippi River delta [50]. It is also comparable to the rates of shoreline retreat attributed to the impacts of Hurricanes Rita and Ike reported from the Chenier Plains of southwestern Louisiana [51].

\subsection{Impacts of Individual Hurricanes on Shoreline Morphology}

Individual hurricanes greatly impacted the barrier beach morphology at Bay Champagne. Comparing shoreline configurations after hurricanes in 2005 and 2008 indicates that each pair of storms produced unique impacts on the barrier beach. Though the two storms to impact this region (Hurricane Katrina in 2005 and Hurricane Gustav in 2008) were of similar magnitude and made landfall in nearby locations, one (Katrina) produced a significant breach while the other (Gustav) resulted in two small breaches but much more overwash. The second hurricane in each pair that occurred during those years (Rita in 2005 and Ike in 2008) that did not come within $200 \mathrm{~km}$ of Bay Champagne likely compounded the impacts of the first storm in the pair. However, these indirect impacts are difficult to quantify.

It is important to note that not all Gulf hurricanes that tracked within $200 \mathrm{~km}$ of Bay Champagne appear to have impacted the site. In 1985, three hurricanes (Danny, Elena, and Juan) caused major impacts on the Caminada-Moreau headland, including overwash and accelerated shoreline retreat at some sites $[23,37,52]$. However, there is little evidence of these storms reflected in the morphology of the shoreline at Bay Champagne during that year. This indicates that storms that have regional-scale impacts may not affect individual sites in similar ways. 


\subsection{Persistence of Hurricane-Created Shoreline Features}

Some shoreline features that are formed as a result of hurricanes can persist for years at Bay Champagne (Figure 6). Morphologic changes in the barrier beach are not immediately re-worked, likely due to the lack of available sediment supply. Because these hurricane-induced features in the shoreline can last for years, they influence the development of subsequent morphologic features. For example, the large breach created by Hurricanes Katrina and Rita in 2005 was filled in with sediment a year later in 2006. Traces of that feature is still identifiable in 2008, even after the passage of Hurricanes Gustav and Ike. Additionally, consecutive storm impacts appear to have compounding effects on the barrier beach. Normal regional sediment transport appears to be able to compensate for the effects of one or a few hurricanes within a given time period. Years with multiple storms, however, seem to push the barrier beach beyond a tipping point that the environment is not able to mitigate given the lack of sediment supply. Once the barrier beach is disrupted, even smaller, less powerful storms can have significant impacts.

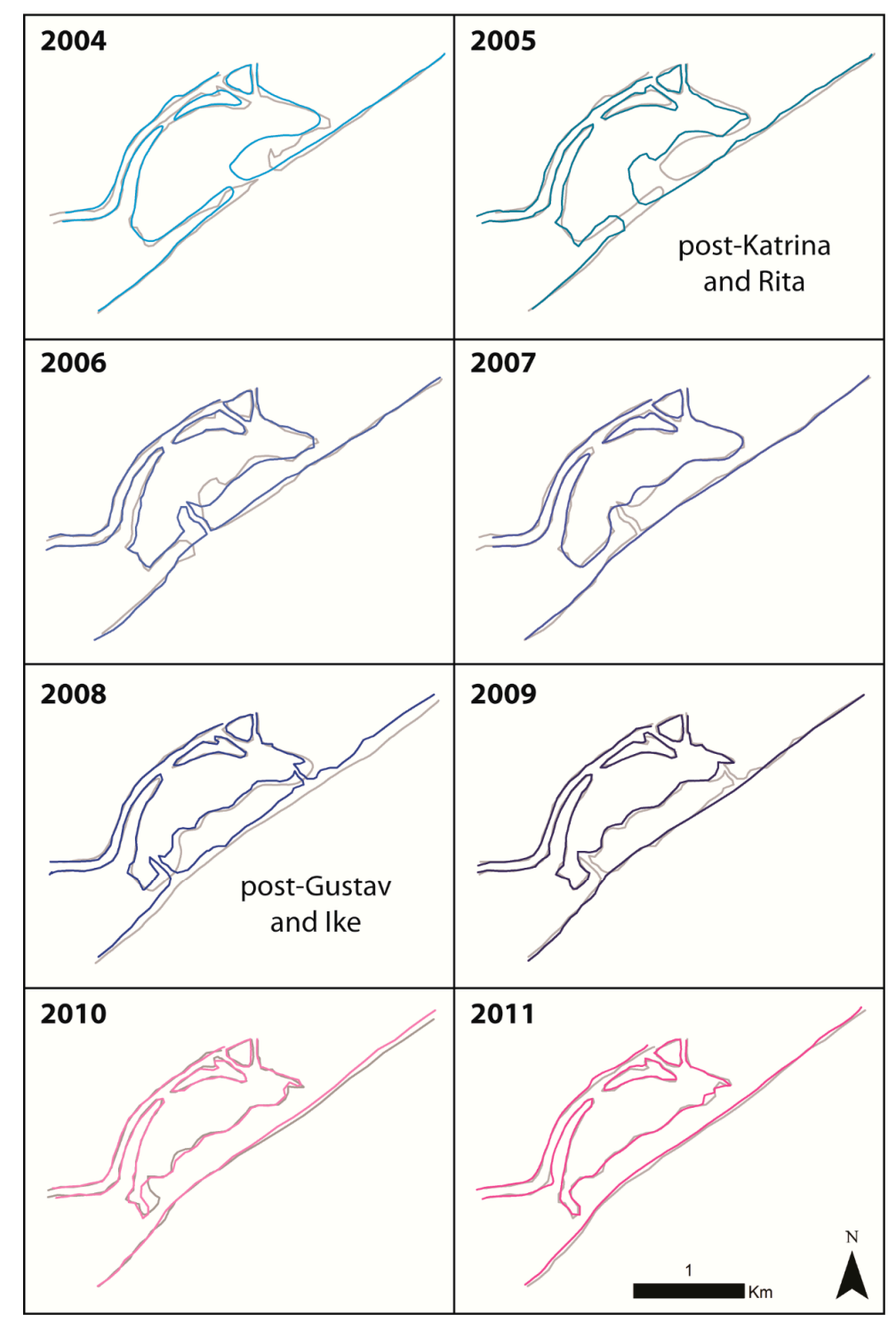

Figure 6. Some coastal features created by hurricanes appear to persist for years at Bay Champagne. Shoreline positions for each year from 2004 to 2011 are shown in sequence. Light grey coastal outlines are from the year prior to the year listed for comparison. 


\section{Conclusions}

This study provides an annual-scale, high-resolution reconstruction of shoreline retreat at Bay Champagne, LA over the past 35 years (1983-2018). The overall rate of shoreline retreat during this period was determined to be $12 \mathrm{~m} / \mathrm{yr}$, confirming the rapid rates of retreat reported in previous studies. This average retreat rate reported in this study classifies Bay Champagne and the Caminada-Moreau headland as a shoreline experiencing "extreme erosion" ( $>5 \mathrm{~m} / \mathrm{yr}$ of retreat), and establishes this stretch of coast as an erosive hot spot as defined by a recent study of the erosion rates of the world's beaches [1]. However, the rate of shoreline retreat at Bay Champagne increased significantly to $>21 \mathrm{~m} / \mathrm{yr}$ during a period of high Gulf of Mexico hurricane frequency from 1998-2013. This rate is higher than any rate of retreat reported by the global study and indicates that average rates of retreat may not accurately reflect the amount of shoreline retreat actually occurring at all shorelines.

The results of this study highlight hurricanes as a major driver of accelerated shoreline retreat in coastal Louisiana, particularly on sediment-starved beaches. The retreat rate corresponding to frequent hurricanes at Bay Champagne was nearly five times higher than the retreat rate during quiet periods with few hurricanes $(\sim 4.7 \mathrm{~m} / \mathrm{yr})$. The retreat rate during quiet periods likely represents "background" rates of shoreline retreat caused by consistent processes such as sea-level rise, subsidence, and winter storm activity. The "background" rate of shoreline retreat at Bay Champagne is also consistent with the average shoreline retreat rate for all of Louisiana [16,49], suggesting that the average rate may not account for hurricane impacts along the Louisiana coast. The significantly higher rate of retreat during the period of frequent hurricanes indicates that these storms effectively exacerbate these "background" rates of shoreline retreat and that the Caminada-Moreau headland will probably again experience extremely accelerated rates of shoreline retreat during future periods of high hurricane frequency.

Shoreline retreat rates are likely to increase in in coastal Louisiana in response to changing climatic conditions. Most climate models predict an increase in hurricane intensity throughout the 21st century due to anthropogenic climate change [53-55]. If this occurs, and the average number of hurricanes remains the same, the shoreline at Bay Champagne will likely retreat faster than predicted. Additionally, the rate of sea level rise is expected to accelerate in the future $[56,57]$ which will correspondingly accelerate the "background" rate of shoreline retreat at Bay Champagne. Even if the other drivers of shoreline retreat remain constant, the combined effect of increasing just these two factors in shoreline retreat could drive future rates of shoreline retreat in this region to unprecedented levels.

Bay Champagne is a microcosm of the past, present, and future of the entire Mississippi River Delta in the face of environmental drivers causing rapid coastal erosion and shoreline retreat. As a result of the rapidly retreating shoreline, Bay Champagne lost nearly half of its surface area in 35 years. If shoreline retreat rates follow the same trend as the previous four decades, and no further efforts are made to artificially mitigate this process, Bay Champagne is expected to disappear into the Gulf of Mexico within the next 40 years. The bleak outlook for Bay Champagne as a result of these processes is also likely the eventual fate of the whole deltaic coast of southern Louisiana. The trends in shoreline retreat identified at Bay Champagne have important implications for coastal management and economic infrastructure, as Port Fourchon, the largest deep-water drilling support facility in southern Louisiana, is situated only 2 miles to the west. While a beach re-nourishment project completed in 2014 was shown to be effective in halting the rapid shoreline retreat at Bay Champagne for a few years, continued observation ( $>5-10$ years) — especially through another period of higher hurricane activity—is needed to ascertain the long-term success of such projects.

Supplementary Materials: The following are available online at http:/ /www.mdpi.com/2073-4441/10/10/1480/s1, Figure S1: Tracks and intensities of hurricanes within 200 kilometers of Bay Champagne (red dot) between 1983 and 2018. Intensity is determined by the strength of the hurricane at landfall. The tracks of stronger hurricanes (Category 2 \& 3) are shown as dotted lines; tracks of Category 1 hurricanes and tropical storms are shown as solid black lines. All but five of these hurricanes occurred between 1997 and 2012. Track and intensity data from NOAA Historical Hurricane Track database (https: / / coast.noaa.gov/hurricanes). 
Author Contributions: Conceptualization, M.E.D., K.-b.L. and T.A.B.; Methodology, M.E.D.; Formal Analysis, M.E.D.; Writing-Original Draft Preparation, M.E.D.; Writing-Review \& Editing, M.E.D., K.-b.L. and T.A.B.

Funding: This research was funded by National Science Foundation [Award Numbers 1212112 and 1735723] and the Society of Women Geographers Evelyn L. Pruitt National Fellowship for Dissertation Research.

Acknowledgments: The authors would like to thank several anonymous reviewers whose thoughtful comments greatly improved this manuscript.

Conflicts of Interest: The authors declare no conflicts of interest.

\section{References}

1. Luijendijk, A.; Hagenaars, G.; Ranasinghe, R.; Baart, F.; Donchyts, G.; Aarninkhof, S. The state of the world's beaches. Sci. Rep. 2018, 8, 6641. [CrossRef] [PubMed]

2. Kantamaneni, K. Coastal infrastructure vulnerability: An integrated assessment model. Nat. Hazards 2016, 84, 139-154. [CrossRef]

3. Syvitski, J.P.M.; Kettner, A.J.; Overeem, I.; Hutton, E.W.H.; Hannon, M.T.; Brakenridge, G.R.; Day, J.; Vörösmarty, C.; Saito, Y.; Giosan, L.; et al. Sinking deltas due to human activities. Nat. Geosci. 2009, 2, 681. [CrossRef]

4. Kantamaneni, K.; Du, X.; Aher, S.; Singh, R.M. Building blocks: A quantitative approach for evaluating coastal vulnerability. Water 2017, 9, 905. [CrossRef]

5. Anthony, E.J.; Marriner, N.; Morhange, C. Human influence and the changing geomorphology of Mediterranean deltas and coasts over the last 6000 years: From progradation to destruction phase? Earth-Sci. Rev. 2014, 139, 336-361. [CrossRef]

6. Bergillos, R.J.; Rodríguez-Delgado, C.; Millares, A.; Ortega-Sánchez, M.; Losada, M.A. Impact of river regulation on a Mediterranean delta: Assessment of managed versus unmanaged scenarios. Water Resour. Res. 2016, 52, 5132-5148. [CrossRef]

7. Bergillos, R.J.; López-Ruiz, A.; Ortega-Sánchez, M.; Masselink, G.; Losada, M.A. Implications of delta retreat on wave propagation and longshore sediment transport-Guadalfeo case study (southern Spain). Mar. Geol. 2016, 382, 1-16. [CrossRef]

8. Penland, S.; Connor, P.F., Jr.; Beall, A.; Fearnley, S.; Williams, S.J. Changes in Louisiana's shoreline: 1855-2002. J. Coast. Res. 2005, SI 44, 7-39.

9. Penland, S.; Ramsey, K.E. Relative sea-level rise in Louisiana and the Gulf of Mexico: 1908-1988. J. Coast. Res. 1990, 6, 323-342.

10. Penland, S.; Suter, J.R. Barrier island erosion and protection in Louisiana: A coastal geomorphological perspective. Gulf Coast Assoc. Geol. Soc. Trans. 1988, 38, 331-342.

11. McBride, R.A.; Byrnes, M.R. Regional variations in shore response along barrier island systems of the Mississippi River delta plain: Historical change and future prediction. J. Coast. Res. 1997, 13, 628-655.

12. Kulp, M.; Penland, S.; Williams, S.J.; Jenkins, C.; Flocks, J.; Kindinger, J. Geologic framework, evolution, and sediment resources for restoration of the Louisiana coastal zone. J. Coast. Res. 2005, SI 44, 56-71.

13. Blum, M.D.; Roberts, H.H. Drowning of the Mississippi delta due to insufficient sediment supply and global sea-level rise. Nat. Geosci. 2009, 2, 488. [CrossRef]

14. Ramsey, K.E.; Penland, S.; Roberts, H.H. In Implications of accelerated sea-level rise on Louisiana coastal environments. In Proceedings of the Specialty Conference on Quantitative Approaches to Coastal Sediment Processes, Seattle, WA, USA, 25-27 June 1991; pp. 1207-1222.

15. Harper, J. Sediment dispersal trends of the Caminada-Moreau beach-ridge system. Gulf Coast Assoc. Geol. Soc. Trans. 1977, 27, 283-289.

16. Martinez, L.; O’Brien, S.; Bethel, M.; Penland, S.; Kulp, M. Louisiana Barrier Island Comprehensive Monitoring Program (BICM) Volume 2: Shoreline Changes and Barrier Island Land Loss 1800's-2005; Pontchartrain Institute Report Study; Pontchartrain Institute: New Orleans, LA, USA, 2009.

17. Penland, S.; Zganjar, C.; Westphal, K.A.; Connor, P.; List, J.; Williams, S.J. Shoreline Changes in the Caminada-Moreau Headland and Grand Isle-1887 to 1996 Lafourche and Jefferson Parishes, Louisiana; USGS Open File Report; USGS: Reston, VA, USA, 2003.

18. Henry, K.M.; Twilley, R.R. Soil development in a coastal Louisiana wetland during a climate-induced vegetation shift from salt marsh to mangrove. J. Coast. Res. 2013, 29, 1273-1283. [CrossRef] 
19. Penland, S.; Ritchie, W. Short term morphological changes along the Caminada-Moreau coast, Louisiana. Gulf Coast Assoc. Geol. Soc. Trans. 1979, 29, 342-346.

20. Penland, S.; Suter, J.R.; Moslow, T.F. Inner-shelf shoal sedimentary facies and sequences: Ship Shoal, northern Gulf of Mexico. In Proceedings of the Modern and Ancient Shelf Clastics, 9th September, Core Workshop, Atlanta, GA, USA, 1986; pp. 73-123.

21. DeWitt, N.T.; Flocks, J.G.; Hansen, M.; Kulp, M.; Reynolds, B. Bathymetric Survey of the Nearshore from Belle Pass to Caminada Pass, Louisiana: Methods and Data Report; U.S. Geological Survey Science Data Series 312; Reston, VA, USA, 2007.

22. Mossa, J.; Penland, S.; Moslow, T.F. Coastal Structures in Louisiana's Barataria Bight; Louisiana Geological Survey: Baton Rouge, LA, USA, 1985.

23. Ritchie, W.; Penland, S. Rapid dune changes associated with overwash processes on the deltaic coast of south Louisiana. Mar. Geol. 1988, 81, 97-122. [CrossRef]

24. NOAA Tides and Currents. Relative Sea Level Trend 8761724-Grand Isle, Louisiana. Available online: https:/ / tidesandcurrents.noaa.gov/sltrends/sltrends_station.shtml?id=8761724 (accessed on 19 June 2018).

25. Meckel, T.; ten Brink, U.S.; Williams, S.J. Current subsidence rates due to compaction of Holocene sediments in southern Louisiana. Geophys. Res. Lett. 2006, 33. [CrossRef]

26. Zou, L.; Kent, J.; Lam, N.S.-N.; Cai, H.; Qiang, Y.; Li, K. Evaluating land subsidence rates and their implications for land loss in the lower Mississippi River basin. Water 2016, 8, 10. [CrossRef]

27. Georgiou, I.Y.; FitzGerald, D.M.; Stone, G.W. The impact of physical processes along the Louisiana coast. J. Coast. Res. 2005, 44, 72-89.

28. Ritchie, W.; Penland, S. Cyclical changes in the coastal dunes of southern Louisiana. J. Coast. Res. 1988, 3 , 111-114.

29. Moeller, C.C.; Huh, O.K.; Roberts, H.H.; Gumley, L.E.; Menzel, W.P. Response of Louisiana coastal environments to a cold front passage. J. Coast. Res. 1993, 9, 434-447.

30. Siadatmousavi, S.M.; Jose, F. Winter storm-induced hydrodynamics and morphological response of a shallow transgressive shoal complex: Northern Gulf of Mexico. Estuar. Coast. Shelf Sci. 2015, 154, 58-68. [CrossRef]

31. Boyd, R.; Penland, S. Washover of deltaic barriers on Louisiana coast. AAPG Bull. 1981, 65, 1682.

32. Walker, N.D.; Hammack, A.B. Impacts of winter storms on circulation and sediment transport: Atchafalaya-Vermilion Bay region, Louisiana, USA. J. Coast. Res. 2000, 16, 996-1010.

33. Kobashi, D.; Jose, F.; Stone, G. In Impacts of fluvial fine sediments and winter storms on a transgressive shoal, off south-central Louisiana, USA. J. Coast Res. Gold Coast Aust. 2007, 50, 858-862.

34. Safak, I.; Sheremet, A.; Allison, M.A.; Hsu, T.J. Bottom turbulence on the muddy Atchafalaya shelf, Louisiana, USA. J. Geophys. Res. Oceans 2010, 115, C12019. [CrossRef]

35. Hardy, J.W.; Henderson, K.G. Cold front variability in the southern United States and the influence of atmospheric teleconnection patterns. Phys. Geogr. 2003, 24, 120-137. [CrossRef]

36. Stone, G.W.; Grymes, J.M., III; Dingler, J.R.; Pepper, D.A. Overview and significance of hurricanes on the Louisiana coast, USA. J. Coast. Res. 1997, 13, 656-669.

37. Penland, S.; Debusschere, K.; Westphal, K.A.; Suter, J.R.; McBride, R.A.; Reimer, P.D. The 1985 hurricane impacts on the Isles Dernieres, Louisiana: A temporal and spatial analysis of the coastal geomorphic changes. Gulf Coast Assoc. Geol. Soc. Trans. 1989, 39, 455-470.

38. Bianchette, T.; Liu, K.-B.; Qiang, Y.; Lam, N. Wetland accretion rates along coastal Louisiana: Spatial and temporal variability in light of Hurricane Isaac's impacts. Water 2016, 8, 1. [CrossRef]

39. Nyman, J.; Crozier, C.; DeLaune, R. Roles and patterns of hurricane sedimentation in an estuarine marsh landscape. Estuar. Coast. Shelf Sci. 1995, 40, 665-679. [CrossRef]

40. Cahoon, D.R.; Reed, D.J.; Day, J.W., Jr.; Steyer, G.D.; Boumans, R.M.; Lynch, J.C.; McNally, D.; Latif, N. The influence of Hurricane Andrew on sediment distribution in Louisiana coastal marshes. J. Coast. Res. 1995, 21, 280-294.

41. Greater Lafourche Port Commission. Port Fourchon-Port Facts. Available online: http://portfourchon.com/ seaport/port-facts / (accessed on 17 June 2018).

42. Penland, S.; Boyd, R.; Nummedal, D.; Roberts, H. Deltaic barrier development on the Louisiana coast. Gulf Coast Assoc. Geol. Soc. Trans. 1981, 31, 471-476.

43. Coastal Engineering Consultants Inc. Caminada Headland Beach and Dune Restoration (BA-45) Completion Report; Coastal Protection and Restoration Authority: Baton Rouge, LA, USA, 2015. 
44. Whitehurst, C.A.; Self, R. Sediment Transport and Erosion in the Fourchon Area of Lafourche Parish; NTRS: Baton Rouge, LA, USA, 1974.

45. Naquin, J.D.; Liu, K.-B.; McCloskey, T.A.; Bianchette, T.A. Storm deposition induced by hurricanes in a rapidly subsiding coastal zone. J. Coast. Res. 2014, SI 70, 308-313. [CrossRef]

46. Liu, K.-B.; Li, C.; Bianchette, T.A.; McCloskey, T.A.; Yao, Q.; Weeks, E. Storm deposition in a coastal backbarrier lake in Louisiana caused by Hurricanes Gustav and Ike. J. Coast. Res. 2011, SI 64, 1866-1870.

47. Daniels, R.C. In Using Arcmap to extract shorelines from Landsat TM and ETM+ data. In Proceedings of the 32nd ESRI International Users Conference, San Diego, CA, USA, 23-27 July 2012.

48. Morton, R.A.; Barras, J.A. Hurricane impacts on coastal wetlands: A half-century record of storm-generated features from southern Louisiana. J. Coast. Res. 2011, 27, 27-43. [CrossRef]

49. Penland, S.; Roberts, H.; Williams, S.; Sallenger, A., Jr.; Cahoon, D.R.; Davis, D.W.; Groat, C. Coastal land loss in Louisiana. Gulf Coast Assoc. Geol. Soc. Trans. 1990, 40, 685-699.

50. Fearnley, S.M.; Miner, M.D.; Kulp, M.; Bohling, C.; Penland, S. Hurricane impact and recovery shoreline change analysis of the Chandeleur Islands, Louisiana, USA: 1855 to 2005. Geo-Mar. Lett. 2009, 29, 455-466. [CrossRef]

51. Yao, Q.; Liu, K.-B.; Ryu, J. Multi-proxy characterization of Hurricanes Rita and Ike storm deposits in the Rockefeller Wildlife Refuge, southwestern Louisiana. J. Coast. Res. 2018, SI 85, 841-845. [CrossRef]

52. Penland, S.; Suter, J.R.; Sallenger, A.H., Jr.; Williams, S.J.; McBride, R.A.; Westphal, K.E.; Reimer, P.D.; Jaffe, B.E. Morphodynamic signature of the 1985 hurricane impacts on the northern Gulf of Mexico. In Coastal Zone'89, Proceedings of the Sixth Symposium on Coastal and Ocean Management, the Omni Hotel, Charleston, SC, USA, 11-14 July 1989; ASCE: New York, NY, USA, 1989; pp. 4220-4234.

53. Elsner, J.B.; Kossin, J.P.; Jagger, T.H. The increasing intensity of the strongest tropical cyclones. Nature 2008, 455, 92. [CrossRef] [PubMed]

54. Villarini, G.; Vecchi, G.A. Projected increases in North Atlantic tropical cyclone intensity from CMIP5 models. J. Clim. 2013, 26, 3231-3240. [CrossRef]

55. Webster, P.J.; Holland, G.J.; Curry, J.A.; Chang, H.-R. Changes in tropical cyclone number, duration, and intensity in a warming environment. Science 2005, 309, 1844-1846. [CrossRef] [PubMed]

56. Nicholls, R.J.; Cazenave, A. Sea-level rise and its impact on coastal zones. Science 2010, 328, 1517-1520. [CrossRef] [PubMed]

57. Rahmstorf, S. A semi-empirical approach to projecting future sea-level rise. Science 2007, 315, 368-370. [CrossRef] [PubMed] 